\title{
The study of some phenotype and physiological characteristic of water hyacinth Eichhornia crassipes (Mart.) Solms-Laubach on different regions of Thi-qar governorate .
}

\author{
Sabah N. Nasir , Alia H. Talib, Suham Z. Manshad and Abdul -Wahab R. Ayyal \\ Biology department, College of education for pure science , University of Thiqar.
}

\begin{abstract}
The plant of water hyacinth Eichhornia crassipesis an abundant floating aquatic weed that has great potential for reproduction in Iraq especially at Thi-Qar governorateat last years, So the study was conducted on plant at three different regions to know the differences on some phenotypic characters are ( plant high, root longs, number of leaves, leaf area and the fresh and the dry weights of leaves ). The results were revealed a clear difference at plant high, root longs, number of leaves, leaf area, fresh and dry weights of plant shoots, also concentrations of chlorophyll, carotenoids, carbohydrates and proteins were estimated. It was found that a clear difference on the concentrations of the components that were studied.

The ability of plant for extraction and accumulation of some heavy metals ( $\mathrm{Pb}, \mathrm{Cd}, \mathrm{Cu}, \mathrm{Zn}$ and $\mathrm{Mn}$ ) and its concentrations on plant tissues, water and soils were studied. The results were showing that, concentrations of heavy metals ranged between( $0.32-25.24$ ) $\mathrm{mg} / \mathrm{gm}$ on the plant tissues, whereas ranged between ( $0.09-2.40$ ) $\mathrm{mg} / \mathrm{l}$ on water and ranged betwee ( $0.53-$ 26.66 ) $\mathrm{mg} / \mathrm{gm}$ on plant soil . From the results, it was noticed that, the high concentration of lead and the low concentration of cadmium .
\end{abstract}

Key words : vegetative growth, heavy metals, water, sediments, water hyacinth 
ISSN Onlin:2708-9347, ISSN Print: 2708-9339 Volume 9, Issue 1 (2020) PP 54-62

https://jam.utq.edu.iq/index.php/main D Doi: https://doi.org/10.54174/UTJagr.Vo9.N1/07

\section{Introduction}

The water hyacinth (Eichhorni acrassipes (Mart) Solms-Laubach belongs to the family (Pontederiacae, a herbaceous plant of the same feces. It is floating in water bodies, growing, multiplying rapidly, consuming large quantities of water, absorbing large quantities of dissolved oxygen in water Which causes a change in the properties of water and make it smell foul and thus be polluted environment and a real threat to aquatic organisms in the countries in which it is located, and the plant is the most dangerous aquatic plants, which exists in the form of stable colonies in shallow water and deep, fixed or moving, Fresh and Fresh (Villamagna, 2009). The native Atlantic is tropical or subtropical in South America, and there are currently plants in the warm world of the world (Agunbiade et al., 2009), It is currently spread in more than 50 countries between latitudes 39 North and 39 South (Centeret et al., 2005). The plant grows in the form of a dense vegetative surface on the surface of the water, formed by a large mass in a short period of time as a result of its rapid multiplication. Of this capacity and has the potential to

re-grow by various means in the event of abnormal conditions such as control, rapid response and adaptation to environmental changes and severely affects the ecosystem, which is not a problem in its native habitat due to the existence of ecological balance (Tellez, 2008).

The plant of the Nile Flower is a plant that has spread in the last decades to various continents of the world from the original home in South America to different parts of the world, including Iraq, and the plant has the ability to grow rapidly and its biomass is very large and bears a number of heavy metals (Suchismitaet al., 2016), and the lack of sufficient knowledge of the nature of plant growth under environmental conditions in Iraq, the purpose of the study was to understand how the plant grow under different environmental conditions on the one hand and to studying some of the vegetative and plant properties of the plant and knowledge of its ability to accumulate heavy metal elements on the other.

\section{Materials and Methods:}

This study included the collection of plant samples from three sites, the first from the Euphrates river and its branches (the city of Nasiriyah St1), the second from the Graf river (St2), the third from the water of Al Eslah district (St3) and collected samples of water and soil for the study sites. The samples were collected by three replicates and each of the three sites, The following: 1. Indicators of vegetative and root growth:

The height of the plant $(\mathrm{cm})$ was measured by the metric tape, as well as the average number of leaves calculated by taking the mean of the three replicates for each of the studied sites.

2. Soft and dry weight of leaves: 


\section{ISSN Onlin:2708-9347, ISSN Print: 2708-9339 Volume 9, Issue 1 (2020) PP 54-62}

\section{https://jam.utq.edu.iq/index.php/main $\quad$ Doi: https://doi.org/10.54174/UTJagr.Vo9.N1/07}

The weight of the leaves was estimated by a sensitive balance and the weights were recorded. The samples were then placed in the incubator for drying at $75^{\circ} \mathrm{C}$ for 48 hours and then weighed after cooling to determine the dry weight of the leaves.

3 - the leave area of the plant:

The leave area of three leaves randomly taken from each plant species was calculated according to their location using the equation (Mckee, 1964):

the leave area $\mathrm{cm} 2=1.25 \times 3.143 \times$ Paper length $(\mathrm{cm}) \times$ Width $(\mathrm{cm})$

4 - Determination of protein concentrations and dissolved carbohydrates:

(Herbert et al., 1971), about $200 \mathrm{mg}$ of fresh samples and was crushed with $10 \mathrm{~cm} 3$ of distilled water in a ceramic vase and then centrifuged for 15 minutes. (50) for 30 minutes. The centrifuge was then reused and leachate free of solids and chlorophyll was taken. The absorbance of the protein was measured using a( Spectro SC Labomed )In spectral device of American origin at wavelength of 600 nanometers Carbohydrate uptake was measured at wavelength (490) $\mathrm{nm}$.

5- Determination of the concentrations of plant pigments:

The concentration of chlorophyll was determined by the modified Arnon-Makinny method (2004). The weight of 100 mg of fresh plant leaves was crushed with $10 \mathrm{~cm} 3$ of acetone at $80 \%$ by ceramic mortar. The filtered was read at the wavelength (663 and 645) $\mathrm{nm}$ using the process of the centrifugation process at a rate of 3000 cycles / min for 5 minutes. Optical spectrometer The chlorophyll concentrations were calculated according to the formula described by (Arnon, 1949).

Mg. g $^{-1}$ chlorophyll a / mg tissue $=[12.7$ (D663)] $-[2.69$ (D645)] x v (100xw)

Mg. $g^{-1}$ chlorophyll b / mg tissue $=[22.9$ (D645)] $-[4.68 D 633]$ x v (100xw)

Mg. $g^{-1}$ chlorophyll $/$ mg tissue $=[20.2(D 645)]+[18.2(D 633)] \times v(100 \times w)$

$V=$ the final size of the filter $(\mathrm{cm} \mathrm{3)}$.

$\mathrm{D}=$ Optical density of chlorophyll extract.

$\mathrm{W}=$ fresh weight $(\mathrm{g})$.

Carotenoids were estimated at wavelength (480) nanometers by the method described by Davies (1965) and calculated on the basis of the following equation:

Optical intensity at wavelength (480) x Total solution size $\times 1000$

Total carotene $(\mathrm{mg} / \mathrm{gm})=$ $10 x$ $-100 \times 250$ 
Heavy metals:

The total heavy metals (both soluble and suspended) were estimated in the water samples by taking $50 \mathrm{~cm} 3$ of the water sample and $5 \mathrm{~cm} 3$ of nitric acid was added to it and then heated at $70^{\circ} \mathrm{C}$ to pre $-(3)$ of $\mathrm{HCl}(0.5 \mathrm{~N})$ for the purpose of dissolving the salt, and then complete the volume with ions free distilled water to $25 \mathrm{~cm} 3$ and save in plastic bottles until measured with the British 986 British Atomic Absorption Spectrometer (APHA) , 2003). Extraction of heavy metals from soils was followed by Yietal (2007). The extraction of heavy metals from the Nile vegetation was adopted (Orson et al., 1992) in the extraction process.

\section{Statistical analysis:}

The statistical comparison between the averages was performed by the analysis of variance (ANOVA), using the (T test). The statistical program Spss 11 was used, and the least significant difference was used at the moral level $(P<.05)$, (Narrator and Behind God, 2000).

\section{Results and discussion:-}

The results in Table (1) show the apparent differences in plant height rates in the different studied sites, and this difference may be due to the plant growth method in these sites. When increasing its density in the area unit, the plant tends to increase in height, While the plant density of the unit of area is few, the plant tends to horizontal growth more than vertical growth, as well as note the difference in the rate of the number of papers and may be due to the composition or increase the number of leaves when available food and heat appropriate but the number varies according to the nature of plant growth, a For months when the formation of new leaves is lacking, the plant tends to form new leaves. By noting the table above, the number of leaves is not as important, but the leave area is important because the nature of the growth of this plant can produce a large number of leaves, especially in the cold atmosphere, but the leave area is limited. ～(Didham, et al., 2005; Wilson et al., 2005) Table (1) :shows the phenotypic characteristics of the Nile flower plant in different locations

\begin{tabular}{|l|c|c|c|c|c|}
\hline \multirow{2}{*}{ Location } & $\begin{array}{c}\text { Average } \\
\text { Leave dry } \\
\text { weight }(\mathrm{g})\end{array}$ & $\begin{array}{c}\text { Average } \\
\text { Leave fresh } \\
\text { weight }(\mathrm{g})\end{array}$ & $\begin{array}{c}\text { Average } \\
\text { Leave area } \\
\left(\mathrm{cm}^{2}\right)\end{array}$ & $\begin{array}{c}\text { Average } \\
\text { number of } \\
\text { Leave }\end{array}$ & $\begin{array}{l}\text { Average } \\
\text { Root lengths (cm) }\end{array}$ \\
\hline
\end{tabular}


ISSN Onlin:2708-9347, ISSN Print: 2708-9339 Volume 9, Issue 1 (2020) PP 54-62

\begin{tabular}{|c|c|c|c|c|c|c|}
\hline St1 & 10.00 & 86.00 & 2.82 & 9.00 & 12.27 \\
\hline St2 & 12.00 & 90.00 & 4.71 & 8.00 & 14.92 \\
\hline St3 & 12.00 & 88.00 & 5.89 & 15.00 & 16.9 \\
\hline LSD & 0.00 & 2.00 & 1.18 & 0.66 & 1.17 \\
\hline
\end{tabular}

Table (2) shows the apparent differences in the ratio of chlorophyll, carotene, carbohydrates and protein. This means that the increase in the area occupied by plants is due to the production capacity of photosynthesis. This means that the rate of photosynthesis is very high compared to other plants or jungles. Which indirectly encouraged the spread and difficulty of combating it. Evidence of this was observed to have a high positive relationship between the leave area and the number of leaves and dry weight with the area occupied by the plant (Al-Waka'a, 2012).

Table (2): shows that $(\%)$ of chlorophyll $(a, b)$ total carotene, carbohydrates and protein:

\begin{tabular}{|c|c|c|c|c|c|}
\hline \multirow{2}{*}{ Location } & Chlorophyll a & Chlorophyll b & Total Carotene & Carbohydrates & Protein \\
& & & & & \\
\hline St1 & 41.87 & 39.20 & 1.61 & 34.02 & 10.62 \\
\hline St2 & 45.36 & 39.24 & 1.98 & 46.11 & 15.43 \\
\hline St3 & 47.14 & 41.73 & 3.99 & 51.25 & 15.25 \\
\hline LSD & 1.78 & 0.03 & 0.36 & 5.13 & 0.17 \\
\hline
\end{tabular}

As for the heavy metals measured in the study sites, there were significant differences between the heavy metals estimated in the water of the stations, except for copper. The location (2) differed from the rest of the water at the level of P (0.05) The highest concentration of lead at site (3) and the lowest concentration of cadmium in situ (1) was due to the large amount of water from nearby residential areas, the container of wastewater and household waste, as well as proximity to the sites a The differences in the concentration of minerals studied according to the studied mineral composition to the suspended particulate matter and the tendency of most of these minerals to adsorption and binding on the surfaces of the suspended particulate matter, organic matter and mud in the water column.( Edword et al, 2013) 
Table (3): Concentrations of heavy metals in water (mg / L)

\begin{tabular}{|c|c|c|c|c|c|}
\hline location & $\mathrm{Cd}$ & $\mathrm{Cu}$ & $\mathrm{Mn}$ & $\mathrm{Pb}$ & $\mathrm{Zn}$ \\
\hline St1 & $0.09 \pm 0.01^{c}$ & $0.53 \pm 0.030^{b}$ & $0.60 \pm 0.015^{a}$ & $0.57 \pm 0.01^{c}$ & $0.43 \pm 0.020^{c}$ \\
\hline St2 & $0.48 \pm 0.02^{a}$ & $0.76 \pm 0.025^{a}$ & $0.20 \pm 0.020^{c}$ & $1.80 \pm 0.01^{b}$ & $0.64 \pm 0.025^{b}$ \\
\hline St3 & $0.31 \pm 0.45^{b}$ & $0.43 \pm 0.030^{b}$ & $0.39 \pm 0.020^{b}$ & $2.40 \pm 0.10^{\mathrm{a}}$ & $1.06 \pm 0.020^{\mathrm{a}}$ \\
\hline LSD & 0.16 & 0.10 & 0.17 & 0.60 & 0.22 \\
\hline
\end{tabular}

As for the heavy metals whose concentrations were estimated in the soil of the study sites, no significant differences were observed between the two sites ( 2 and 3 ) for the cadmium and magnesium minerals. The rest of the other minerals found significant differences in the studied sites (as shown in Table 2). The highest concentration of $\mathrm{Pb}$ was recorded in site (1) and the lowest concentration of cadmium in situ (3). This may be due to uneven concentrations of the minerals studied in the sediment, or possibly due to dust storms and rainwater contaminated with high concentrations of these minerals to the river water and likely Also to the effect $\mathrm{b}$ Environmental factors in the release or retention of heavy metals, $\mathrm{pH}$ values, salinity and soil tissue also play an important role in reducing the toxicity of heavy metals to aquatic organisms because they form complexes with chlorine ion, making the metal not readily available for use and sedimentation, Minerals in Sediments (AlKinzawi, 2007)

Table (4) :Trace elements in soils ( $\mathrm{mg} \cdot \mathrm{g}^{-1}$ )

\begin{tabular}{|c|c|c|c|c|c|}
\hline Metals & & & & & \\
Location & $\mathrm{Cd}$ & $\mathrm{Cu}$ & $\mathrm{Mn}$ & $\mathrm{Zn}$ \\
\hline St1 & $0.64 \pm 0.05^{\mathrm{a}}$ & $9.4 \pm 0.025^{\mathrm{a}}$ & $3.2 \pm 0.020^{\mathrm{a}}$ & $26.66 \pm 0.010^{\mathrm{a}}$ & $7.4 \pm 0.030^{\mathrm{c}}$ \\
\hline St2 & $0.57 \pm 0.025^{\mathrm{b}}$ & $7.3 \pm 0.025^{\mathrm{b}}$ & $1.60 \pm 0.030^{\mathrm{b}}$ & $17.47 \pm 0.015^{\mathrm{b}}$ & $3.4 \pm 0.020^{\mathrm{b}}$ \\
\hline
\end{tabular}


ISSN Onlin:2708-9347, ISSN Print: 2708-9339 Volume 9, Issue 1 (2020) PP 54-62

https://jam.utq.edu.iq/index.php/main D Doi: https://doi.org/10.54174/UTJagr.Vo9.N1/07

\begin{tabular}{|c|c|c|c|c|c|}
\hline St3 & $0.53 \pm 0.035^{\mathrm{b}}$ & $3.5 \pm 0.040^{\mathrm{c}}$ & $2.35 \pm 0.030^{\mathrm{b}}$ & $13.01 \pm 0.010^{\mathrm{c}}$ & $1.06 \pm 0.015^{\mathrm{c}}$ \\
\hline LSD & 0.05 & 2.09 & 0.72 & 4.36 & 0.77 \\
\hline
\end{tabular}

As for the concentrations of heavy metals estimated in the Nile flower plant, there were significant differences between the concentration of lead only in the studied sites. There were no significant differences between their concentrations at the studied sites (as shown in Table 3). This is probably due to the cumulative capacity of aquatic plants. In addition, some aquatic plants can take heavy metals associated with sediments and water through the root system, as well as by analyzing the mineral content of the plant gives a good indication of the state. The aquatic environment and what may have been exposed to it. Therefore, the study of the plant, which can be prevalent in these sites, which may be used as food for aquatic and also the reason for the presence of these minerals in the tissues of the plant, may be due to the ability of the plant to introduce some heavy metals that are essential to plant life through the process of effective transport, when exposed to heavy metals, water plants produce phytochelatins, which are rich in thiol, which in turn interferes with the removal of the toxicity and natural balance of heavy metals in plants (AL - Ebady, 2015). This is done by the phytochelatins synthase, which activates the presence of heavy metal ions stamla the glutathione-based poultice, and the cells in response depends on the existing metal type (AlHaidari, 2003).

Table (5) :Concentrations of heavy metals in plants ( $\mathrm{mg} / \mathrm{g}$ )

\begin{tabular}{|c|c|c|c|c|c|}
\hline Metals & $\mathrm{Cd}$ & $\mathrm{Cu}$ & $\mathrm{Mn}$ & $\mathrm{Pb}$ & $\mathrm{Zn}$ \\
\hline St1 & $4.16 \pm 0.03^{\mathrm{a}}$ & $9.1 \pm 0.08^{\mathrm{a}}$ & $0.23 \pm 0.025^{\mathrm{b}}$ & $25.24 \pm 0.010^{\mathrm{a}}$ & $16.5 \pm 0.015^{\mathrm{a}}$ \\
\hline St2 & $2.63 \pm 0.04^{\mathrm{a}}$ & $7.3 \pm 0.03^{\mathrm{b}}$ & $1.02 \pm 0.010^{\mathrm{a}}$ & $23.42 \pm 0.030^{\mathrm{b}}$ & $13.51 \pm 0.015^{\mathrm{b}}$ \\
\hline St3 & $0.32 \pm 0.04^{\mathrm{b}}$ & $1.24 \pm 0.015^{\mathrm{a}}$ & $1.18 \pm 0.020^{\mathrm{a}}$ & $19.67 \pm 0.025^{\mathrm{c}}$ & $12.76 \pm 0.025^{\mathrm{b}}$ \\
\hline LSD & 1.53 & 1.83 & 0.20 & 1.83 & 0.87 \\
\hline
\end{tabular}

\section{References}

1. Agunbiade, F.O. ; Oluowolabi , B.I. and Adebowale, K.O. ( 2009 ) Phytoremediation potential of Echhorniacrassipes in metal contaminated coastl water .Bioresource Technol. , $100: 4521$ - 4526.

2. AL - Ebady W.R.A (2015) Ecological Study of Some Heavy Metals on The Euphrates river Water at Nassiriyah City and The Ability of Accumulation by Some Blue green Algae and Ceratophyllum demersum L. in the Laboratory. Ph.D. Thesis. College of Education For pure science, University of Basrah ,Iraq. 
ISSN Onlin:2708-9347, ISSN Print: 2708-9339 Volume 9, Issue 1 (2020) PP 54-62

\section{https://jam.utq.edu.iq/index.php/main D Doi: https://doi.org/10.54174/UTJagr.Vo9.N1/07}

3. Al -Jawari, N. S.H.(2004) Soak the wheat grains(Triticum aestivum L. ) with ethylene chloricol and its effect on growth and productivity and increase the tolerance to desiccation. M.Sc. Thesis, College of Education, University of Mosul, Iraq.

4. Al-Haidari, M.J.S(2003) Some of the environmental effects of the industrial dirty water removed from Al - Furat Chemical Industries near Siddh Al - Hindi . M.Sc. Thesis, College of Science - Babylon University.

5. Al-Kinzawi, M.A.H. (2007) Ecological study of aquatic macrophytes in the central part of the marshes of southern Iraq. M.Sc. Thesis, College of science for women, Biol. Dept. Baghdad Univ. Iraq.132p.

6. AL-Rawi ,K.M ; Abdul Aziz, K.A (2000) Design and analysis of agricultural experiments . College of Agriculture and Forestry, University of Mosul, Iraq.

7. Al-Waka'a, A.H.A ; Sultan, A. M. ( 2012) Effect of different periods of growth in biomass and productivity of Nile flower plant Eichhornia crassipes (Mart)Solms In northern Iraq. Kufa Journal of Agricultural Sciences,4(2):125-136.

8. APHA , American Public Health Association (2003) Standard methods for the examination of water and waste water . $20^{\text {th }}$ Ed. WashingtonDC. USA.

9. Arnon , D.I. ( 1949 ) Plant physiology . Experimental In plant physiology class. London . George Allen and Cell win . ( Cited by Mediner , H. 1984 ).

10. Center, T.D.;T.K. Van; Dray, J.F. A ; Franks, S. J ; Rebelo, M. T. ; Pratt, P. D. and Rayamajhi, M. B .(2005)Herbivory alters competitive interactions between two invasive aquatic plants. Biological Control . 211 217.

11. Davies, D.H.(1965) Analysis of carotenoid pigmens .(Goodwin,T. wied)Academic Press . London. P:489-532.

12. Didham, R.K; Tylianakis, J.M. ; Hutchison, M.A. ; Ewers, R.M. and Gemmell, N. J. ( 2005) .Are invasive species the drivers of ecological change. Trends in Ecology and Evolution 20.

13. Edward, J. B.; Idowu, E. O.;Oso, J. A. and Ibidapo, O. R.(2013). Determination of heavy metalconcentration in fish samples, sediment and water from Odo-Ayo River in Ado-Ekiti, Ekiti-State, Nigeria, Int. J. of Environ. Monitoring and Analysis, 1(1) : 27-33.

14. Herbert, D .; Philips, P . J . and Strange, R. E . (1971) Methods in Microbiology . Chapter

3. Morris, J.R . and Robbins, D . W . (eds) . Academic Press New York, U . S . A .

15. Mckee,G.W.(1964) Acoefficient for computing leaf area in hybrid corn . Argon. J.,56(2):

240- 241.

16. Orson, R. A.; Simpson, R. L. and Good R. E. (1992) A mechanism for the accumulation and retention of heavy metals in tidal water marshes of the upper Delaware river estuary. Estuarine, Coastal and Shelf Science , 34 :171-186.

17. Suchismits , D. ; Sunayana , G. and Anupam , D. T. ( 2016) Physiologicalresponses of water hyacinth Eichhorniacrassipes (Mart.) Solms, to cadmium and its phytoremediation potential.Turkish . J. Biol . , $40: 84$ - 94 . 
ISSN Onlin:2708-9347, ISSN Print: 2708-9339 Volume 9, Issue 1 (2020) PP 54-62

18. Têllez, T.; de Rodrigo, L_pez, E.M.; Granado, G.L.; Pérez, E.A.; L_pez, R.M. and J.M.S, Guzmá. (2008). The Water Hyacinth, Eichhorniacrassipes: an invasive plant in the Guadiana River Basin (Spain). Aquatic Invasions3: 42-53.

19. Villamagna, A. (2009)The ecological effects of water hyacinth (Eichhorniacrassipes) on Lake Chapala, Mexico. Ph.D. Thesis. Virginia Polytechnic Institute and State University, Blacksburg.

20. Wilson, JR, Holst NandM,Rees.(2005).Determinants and patterns of population growth in water hyacinth. Aquatic Botany 81, 51-67.

21. Yi , L. ; Hong , Y. ; Wang , D. and Zhu , Y. (2007). Determination of free heavy metal ion concentration in soils around a cadmium rich zinc deposit. Geochemical J. , $41: 235-24$ 